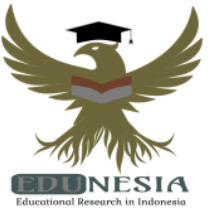

\title{
The Principal of Madrasah Examplary to Improve Teacher performance at MIS Al Azhar Sido Makmur Labuhanbatu
}

\author{
Syawal \\ Madrasah Education Supervisor Kab. Labuhanbatu, Indonesia \\ Corresponding Email: drssyawal@gmail.com, Phone Number:0852 xxxx xxxx
}

\author{
Article History: \\ Received: July 28, 2021 \\ Revised: August 18, 2021 \\ Accepted: Sept 16, 2021 \\ Online First: Okt 10, 2021
}

\section{Keywords:}

The Principal of Madrasah

Examplary,

Teacher Performance.

Kata Kunci:

Keteladanan Kepala Madrasah, Kinerja Guru.

\section{How to cite:}

Syawal, S. (2021). The Principal of Madrasah Examplary to Improve Teacher performance at MIS Al Azhar Sido Makmur Labuhanbatu Edunesia: Jurnal Ilmiah Pendidikan, 2 (3): 696-704.

This is an open access article under the $C C-B Y-N C-N D$ license
Abstrak: In essence, leaders have the ability to influence the behavior of others. This study aims to see how the School Principal's Examplary Leadership in Improving Teacher Performance at MIS Al-Azhar Sido Makmur, Labuhan Batu Regency. Descriptive analysis techniques through observation, interviews, and document studies. Data were obtained from several participants including the school principal ofmadrasa, the deputy head, 5 teachers, and 25 students. The results of the study has been able to give concrete examples to teachers in schools. It is considered as good exemplary leadership. Teacher performance which isseen from work performance among teachers already has strategies, teaching methods, has teaching competence and has a teaching plan and teachers are also responsible for the learning process. The head of the madrasah conducts ongoing evaluations in an effort to realize the vision and mission of education in schools so that they can anticipate various problems that may arise.

Abstrak: Pada hakikatnya pemimpin memiliki kesempatan untuk berpengaruh terhadap perilaku orang lain. Penelitian ini memiliki tujuan untuk melihat Keteladanan Kepala madrasah dalam hal peningkatkan Kinerja Guru di MIS Al- Azhar Sido Makmur Kabupaten Labuhanbatu. Metode dalam penelitian ini menggunakan menggunakan metode kualitatif dengan teknik analisis deskriptif melalui pendekatan observasi, wawancara, dan studi dokumen. Data diperoleh dari narasumber antara lainkepala madrasah, wakil kepala madrasah, 5 guru, dan 25 siswa. Hasil penelitian menunjukkan bahwa penelitian, yaituKeteladanan Kepala Sekolah di Madrasah Ibtidaiyah Swasta Al Azhar Sido Makmur Kabupaten Labuhan batu sudah baik karena sudah dapat mencontohkan hal-hal yang konkrit kepada guru-guru di sekolah. Hal ini dianggap keteladanan yang baik bagi Kinerja Guru yang dilihat dari prestasi kerja diantara guru sudah memiliki strategi, metode mengajar, memiliki kompetensi mengajar dan mempunyai rencana pengajaran serta guru juga sudah bertanggung jawaban dalam proses pembelajaran. Kepala Madrsah melakukan evaluasi berkelanjutan dalam upaya mewujudkan visi dan misi pendidikan yang ada disekolah sehingga dapat mengantisipasi berbagai persoalan yang mungkin muncul. 


\section{A. Introduction}

The principal/head of Madrasah is a teacher who is given the additional task of being a leader in an educational institution in a school under the auspices of the Education Office and the Ministry of Religion. The principal as a leader should provide examples that can be imitated by educators, teachers and students. Although all of this requires a process, but a good example must be done by the principal so that teachers can imitate and apply as the principal does. Guiding, directing teachers to carry out professional duties is not easy to do, it requires patience from the leadership (Kristiawan et al., 2017).

The teacher is someone who shares knowledge with students through the teaching and learning process and has a special field of knowledge and experience in accordance with the educational background he already has in a broad and deep theory (Sardiman, 2011). The teaching and learning process carried out by the teacher is of course to produce quality students, for that it takes a long time for students to have quality. A good teacher who will teach and educate must have preparations before transferring knowledge to their students. Educating is a profession or a professional job because the teacher is the main actor in education.

A teacher who does not make a work program when teaching is not aware of his duties and responsibilities as a teacher. Especially now that there is government assistance provided by teachers, namely certification allowances. The target of the certification allowance is actually the teacher's performance to be more enthusiastic and always provide motivation to students. According to Rusihan (2019), there are several conditions that must be met by someone who becomes a leader, namely: honesty, level of confidence, stability, responsibility, and decisions. Big-hearted, has emotions that are not unstable and also able to be used as role models.

Teachers have an important role in guiding students to be mature and independent, so teachers are often referred to as the spearhead in education. Teachers are a very influential component in the creation of quality educational processes and outcomes. In simple terms, it is easy to say that the role of the teacher is to organize the teaching and learning process, which is to help and facilitate students to experience and implement a quality learning process.

One of the fundamental actors that determine the achievement of the above national education goals is the teacher. The teacher's role is one of the important and strategic components through its performance. Teacher performance is very important in realizing national education goals and determining the high and low quality of education, but the performance of these teachers is heavily influenced by various factors, both internal and external to the individual concerned.

Professional teachers are teachers who can carry out their duties according to their functions and roles both in the teaching and learning process in the classroom and outside the classroom, as a whole must know, appreciate, and deeply understand the gas well, must master the material. Lessons, teaching methods of learning principles as well as creating good teaching and learning interactions, and being able to carry out effective learning evaluations.

The concept of an example has been given by the way Allah sent the Prophet. To be a good role model for Muslims throughout history and for all humans in every time and place. He is like a bright lamp and the moon that guides the way. This example must always be nurtured, nurtured, and guarded by the bearers of the message. The success of an educational implementation will be largely determined by several factors. One of these 
factors is the example of someone who is considered older. Such a person is mainly claimed to be a parent, leader, and teacher.

Behavior that is exemplified in education can be learned from patterns of behavior, and not from traits (educational subjects). This research looks at and identifies typical behaviors in activities learning to influence students to have a positive character. This exemplary behavior can be oriented to the task of the teacher or to relationships with students, the behavior of the teacher's closeness to students can build a conducive learning atmosphere.

Exemplary is one approach in education exemplified by the Messenger of Allah, Allah explicitly states that in sent by the Prophet Muhammad SAW, to be an example for all humanity. Thus the realization of Islamic education lies in principals and teachers in providing an example.

In order to carry out its role and function as an innovator, The principal must have the right strategy to establish harmonious relationship with the environment looking for new ideas, integrating each activity set an example for all. Education staff in schools, and develop innovative learning models. The principal as an innovator must be able to seek, find, and implement various reforms in the schools.

The problem is when in the field there are also many teachers who show low performance, this can be seen by: often late, coming home early, rarely attending, not participating in MGMP activities, being lazy, not having teaching media, rarely giving assignments and others. There is another thing that is even more concerning that the teachers who are diligent in teaching have had enough years of service but have not been lucky enough to take care of the NUPTK. With this problem, the principal as a manager must be able to overcome the problems that occur in schools, especially at the MIS level. The principal in overcoming the problem must be able to provide the right solution when solving the case. For this reason, the author tries to examine the extent to which: "Exemplary Principals in Improving Teacher Performance at MIS Al-Azhar Sido Makmur, Labuhan Batu Regency".

\section{B. Method}

The type of method used in this research is qualitative. Qualitative methods are widely used by researchers in natural object conditions, because this research is the opposite of experimentation. The data analysis technique used is inductive and emphasizes the meaning of generalization. This research was conducted at the Al Azhar Private Islamic School, Sido Makmur, Labuhan Batu Regency. The research subjects were the principal, teachers and homeroom teachers of Class V totaling 5 people and Class V students totaling 25 people. The data on the total number of students are as follows:

Table 1.

The Data students of Madrasah Ibtidaiyah Al Azhar Sido Makmur, Labuhanbatu Regency

\begin{tabular}{ccccc}
\hline No & Class & Male & Female & Total \\
\hline 1 & I & 11 & 16 & 27 \\
2 & II & 12 & 15 & 27 \\
3 & III & 18 & 11 & 29 \\
4 & IV & 16 & 13 & 29 \\
\hline
\end{tabular}




\begin{tabular}{ccccc}
\hline No & Class & Male & Female & Total \\
\hline 5 & V & 10 & 15 & 25 \\
6 & VI & 10 & 21 & 31 \\
& Total & 77 & 91 & 168 \\
\hline
\end{tabular}

Data collection techniques in this study are observation, interviews and documentation. While the data analysis technique goes through the following stages:

1) Collecting data

Data that has been collected through various techniques (documentation, observation, and interviews) and all field notes are also important at this stage.

2) Data Reduction

Reduction is a summary of all existing field notes by taking core things and focusing on important things and related to the scope of research which includes the development of students' personalities at MIS Al Azhar Sido Makmur, Labuhan Batu Regency. All of these records are summarized in a systematic way in order to give an overall picture of the results.

3) Data Display

The data display will later be useful for making it easier for researchers, presented in the form of tables and explain the narrative of the interview results. In the table, a comprehensive picture will be obtained and meaningful conclusions will be drawn.

4) Data Validity Assurance Techniques

The process of drawing conclusions is done by discussing the data that has been found in the field and juxtaposed with existing theories. This process has been carried out since the beginning of the data obtained.

\section{Result and Discussion}

Based on the research data, it was obtained that $90 \%$ of the educators at MIS Al Azhar Sido Makmur, Labuhan Batu Regency, had completed both undergraduate and postgraduate education. This has shown that the quality of existing education is the main thing in improving the quality of graduates. Data on facilities and infrastructure at MIS Al Azhar Sido Makmur, Langkat Regency, has shown a very good/adequate condition, this is also the main capital in developing madrasas in the future.

Based on the research results obtained at MIS Al Azhar Sido Makmur, Labuhan Batu Regency through various data mining techniques, this study resulted in 5 findings in this study.

1) Exemplary Head of Madrasah

Madrasah Ibtidaiyah Swasta Al Azhar Sido Makmur Labuhan Batu Regency is an institution in the field of Islamic education under the auspices of the government, precisely at the Ministry of Religion of the Republic of Indonesia, which as it is known that exemplifying the example of the principal actually begins with the individual principal himself, for example commendable actions, appeals, assisting the completion of BK teachers, giving awards for work performance, and instilling moral values, not cutting off what is not their right.

The principal in his leadership duties will succeed well if he understands the things that have been used as the main tasks that must be carried out. Therefore, in the process of carrying out the task, it will be seen how the head of the Madrasah guides teachers and 
education personnel at the school. The vision and mission of the madrasa will be achieved if the principal also has a professional attitude, where he understands his duties and obligations as a leader. In addition, good cooperative relationships with teachers must also be established so as to create a work atmosphere that is safe, comfortable, peaceful, and has the freedom to develop ideas in order to achieve common goals,

The madrasa principal as a leading example for teachers means having a strong commitment to the rules that apply in the school, daring to take risks against decisions that have been mutually agreed upon and having to take all the responsibility with all the risks. According to Shoimin (2014), the exemplary process is the giving of examples by leaders both in their words and words. This is also in accordance with the opinion of Asmani (2012), which explains the important role of school principals in influencing teachers and all education personnel to achieve the vision and mission that has been set by the school.

If the principal can set a good example, then all school members will follow suit. Based on this, according to Mulyasa, the principal is a person who has roles and functions as educators, supervisors, leaders, innovators and motivators (Mulyasa, 2012). Of the five functions Each of these has its own role but is still in one understanding. The principal can be said to be a leader, according to Covey there are several roles that a leader must have, namely the ability to be a role model, a pioneer, a role in aligning, and an empowerment role (Kaswan, 2013).

According to Makawimbang (2012), there are 4 leader behaviors, namely: commanding, supporting, facilitating, and achievement orientation. A leader who shows exemplary to the teachers is in accordance with the QS Al Ahzab 21, namely:

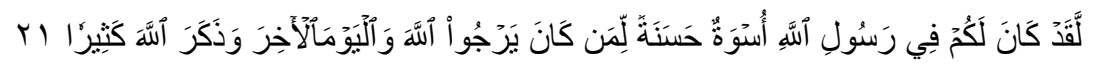

Meaning: Verily there has been in the Messenger of Allah a good role model for you (that is) for those who hope (the mercy of) Allah and (the coming of) the Day of Resurrection and he mentions Allah a lot." (QS. Al Ahzab: 21).

The verse above is clear that the Messenger of Allah has become a role model to be followed in human life. Based on this hadith, it can be concluded that exemplary is likened to the Hadith that the seller of perfume can splash you so that it smells good but if we hang out with a blacksmith, there is a risk if later it gets caught in a fire and burns. Therefore, it is better to be a role model, not only the principal who provides an example, but all teachers and students also provide examples.

2) Improving the Performance of MIS Al Azhar Sido Makmur Teachers, Labuhan Batu Regency

Al Azhar Madrasah Swasta Sido Makmur, Labuhan Batu Regency is under the Al Azhar Private Madrasah Ibtidaiyah Education Foundation, Sido Makmur, Labuhan Batu Regency. The teacher's performance is very much considered by the principal because it is to see or measure the targets of the work that has been done during one school year. It is not only teachers who are the targets of the principal's performance, but all related parties in the school are seen to see the results of their work based on the instruments that have been recorded by the officers. 
The example of the madrasa principal who has been shown to the teacher can direct, guide and carry out his duties. If there is a problem, the madrasa head will discuss with the teacher to find a solution. If it is related to performance, it is related to achievement and work results. Performance is a word in Indonesian from the root word which translates words from foreign languages as achievement, it can also mean work Performance is often called performance, work results or work performance (Wibowo, 2017). Then Michael Armstrong defines "Performance is often defined simply in output terms the achievement of quantified objectives. But performance is a matter not only of what people achieve but how they achieve it" (Amstrong, 2012), performance is defined simply in the context of results, which are achievements of measuring results. So it can be understood that performance is essentially a work achievement obtained and has been carried out within 1 semester for teachers. When combined, teacher performance is the achievement of a teacher obtained through the course of the profession so that it is recognized by the community who are better known as professionals. Teachers are professional educators with the main task of educating, teaching, guiding, directing, training, as well as assessing and evaluating students in early childhood education and formal education, basic education, and secondary education.

As a leader, the principal must be able to be a leader who can be followed by an example of his behavior and actions. Leaders become transeters or intertainment in education. So all actions of the leader or principal must be accountable. Because, the principal is the main example in the school. If the school has good management, then what the principal says can be an example for subordinates. Leaders must have and have various conditions that can be said to be leaders. So what is meant by giving an example is being able to become a leading person, an example and all positive behavior can be imitated by subordinates and the work environment. In this case teachers, students and staff.

Giving examples or doing things before their subordinates do, is not just in the form of writing but must be realized. So before someone can do it, the principal must always have a good idea to realize. A leader will be respected by subordinates if his behavior can be imitated. This automatically makes subordinates reluctant and makes the principal a good example to imitate. Although this is difficult and takes time to do, the principal still has to set a positive example for subordinates to imitate. Both in behavior, speech and personal. In the school, the principal is like the intertainment or the artist. So that everything that is done will be discussed or used as an example. This is where the principal must have qualities that are worthy of being used as examples and not arbitrary in making decisions.

The principal must be able to be perfect or perfect and is expected to be agile in making decisions. Always cheerful and professional will be used as an example and build school comfort. An extroverted principal is a principal who is often used as an idol and an example for his subordinates. For example, by coming every morning before the student or teacher arrives, then if there is a teacher who is late, the next day he will improve himself because he is reluctant to the principal. Helping cleaning staff pick up trash scattered around the school, from examples like this, school members or residents will slowly follow the principal's attitude.

Always going around from class to class and making sure the teaching and learning process runs smoothly, if there is an empty class the principal is not angry, but invites students to come to class and tell stories while waiting for the teacher to come. The principal does not limit students, teachers, principals to communicate with each other as family or friends, provided that authority and courtesy must remain. And there are many other 
examples that the principal can do as an example for his subordinates and school residents. With such attitudes and examples, the school will run better and a sense of family will be created by itself. If everything goes smoothly then this school will be an example, not only in the school environment but can be imitated by other schools as well.

Principal leadership is the motor or driving force of the resources and tools available to an organizational group. Leaders must have good qualities that can be used as examples in the school environment. One of them must be humble or simple, patient or have emotional stability, helpful, confident, honest and expert in his position. The principal must be a role model or example for his employees regarding good behavior, also in terms of discipline or in the academic field. For example, in terms of discipline, the principal can convey regulations. In discipline, the principal can also carry out that discipline, in terms of academics. For example, after checking or evaluating in learning administration. After that, an evaluation is carried out in the learning process. If there is a teacher who is less successful in carrying out the learning process, it can be seen in the results of the assessment achieved by his students. The principal gives an example when making a complete lesson plan with the methods and media used according to the student's circumstances and the existing infrastructure at the school. However, the facts that occur in the field, most of the principals are not able to carry out optimally. This can be influenced by the will from within the principal or because the time has not been planned. The school principal should be able to implement it. If the supervisor can really do according to his duties so that the principal can carry it out.

In carrying out his mandate as a professional teacher, he must have a variety of strategies carried out by the teacher so that the ability of his role in school appears. According to Hamalik 2012), the ability of a teacher in carrying out his role is as follows:

a) As a facilitator, who provides facilities for students to carry out learning activities.

b) As a mentor, who helps students overcome difficulties in the learning process

c) As an environmental provider, which seeks to create an environment that challenges students to carry out learning activities

d) As a communicator who communicates with students and the community

e) As a model who is able to provide a good example for students to behave well

f) As an evaluator, who evaluates student learning progress

g) As an innovator, who participates in disseminating reform efforts to the community

h) As a moral and political agent, who contributes to the moral development of the community, students, and supports development efforts

i) As a cognitive agent, who disseminates knowledge to students and society

j) As a manager who leads a group of students in the class so that the learning process is successful.

From several opinions on teacher performance, it can be concluded that teacher performance actually includes work performance among teachers who must have strategies, teaching methods, have teaching competencies and have teaching plans. The teacher as a responsible component in the educational process and mission as well as the learning process in particular, is very vulnerable to various problems that may arise (Ritonga, 2020).

However, the teacher's performance when associated with QS Al Mujadalah verse 11 as follows:

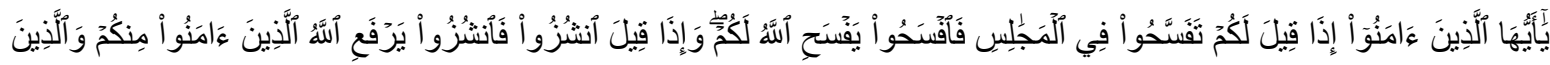

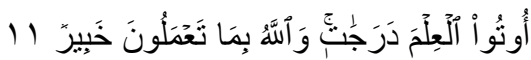


Meaning: "hi you who believe, when it is said to you: "Be spacious in the majlis", then open it up, Allah will certainly make room for you. And when it is said: "Stand ye", then stand up, Allah will surely raise those who believe among you and those who are given knowledge by several degrees. And Allah is Knowing of what you do. (QS al-Mujadalah: 11).

The verse above explains that in principle teachers are part of people who believe and Allah will exalt those who will be given knowledge to some degree through the learning process carried out in schools.

\section{Conclusion}

Based on the analysis and various findings of this study, it can be concluded that the exemplary principals in improving teacher performance at the Al Azhar Sido Makmur, Labuhan Batu Regency are as follows: can give concrete examples to teachers in schools. Teacher performance which is seen from work performance among teachers already has strategies, teaching methods, has teaching competence and has a teaching plan and teachers are also responsible for the learning process. The head of the madrasah conducts ongoing evaluations in an effort to realize the vision and mission of education in schools so that they can anticipate various problems that may arise.

\section{References}

Asmani, J.M. (2012). Tips Menjadi Kepala Sekolah yang Profesional. Djogjakarta. Diva Press.

Asmtrong. (2012). Michael Performance Management Key Strategies and Pratical Guideline $3^{n d}$ Edition. London and Philadelphia : Kogan Page.

Hamalik, O. (2012). Psikologi Belajar dan Mengajar. Bandung: Sinar Baru Algensindo.

Kaswan. (2013). Membangun Tim Efektiv dan Berkinerja Tinggi Melalui Kepemimpinan. Bandung: CV.Alfabeta.

Kementrian Agama RI. (2013). Alqur'an dan Terjemahannya Indonesia. Jakarta:Departemen Agama RI.

Kristiawan, M., Safitri, D., \& Rena Lestari. (2017). Manajemen Pendidikan. Deepublish.

Makawimbang, J.H. (2012). Kepemimpinan Pendidikan yang Bermutu. Bandung: Alfabeta.

Mansur. (2020). Kepemimpinan Kepala Madrasah Dalam Peningkatan Kinerja Guru Di Man Sumbok Kecamatan Nibong Aceh Utara. Al-Fatih: Jurnal Pendidikan dan Keislaman Vol. III. No. 1 Januari- Juni 2020.

Mukhtar. (2015). Strategi kepala sekolah dalam meningkatkanKinerja guru pada SMP Negeri di kecamatanmasjid raya kabupaten aceh besar. Jurnal Magister Administrasi Pendidikan. Volume 3, No. 3, Agustus 2015.

Mulyasa, H.E, 2012. Manajemen dan Kepemimpinan Kepala Sekolah, (Jakarta: Bumi Aksara). 
Rulitawati, M. P. I., Ritonga, H. H., \& Hasibuan, L. (2020). Model Pengelolaan Kinerja Guru. Tunas Gemilang Press.

Rusihan. (2019). Keteladanan Kepemimpinan Kepala Sekolah Dalam Meningkatkan Kinerja Guru Di Sekolah. Jurnal Pembelajaran Prospektif Volume 4 Nomor 2, Agustus 2019.

Shoimin. (2014). Model Pembelajaran Inovatif Dalam Berkurikulum 2013. Yogyakarta : ARRUZZ Media. 